\title{
The Management of Sewage Sludge from Purge Water in Romanian Agriculture
}

\author{
Marius SABĂU* \\ Department of Economics. University of Agriculture and Veterinary Medicine \\ Cluj-Napoca, Romania \\ *Corresponding author: marius.sabau@usamvcluj.ro \\ Bulletin USAMV series Agriculture 72(2)/2015 \\ Print ISSN 1843-5246; Electronic ISSN 1843-5386 \\ DOI 10.15835/buasvmcn-agr: 11737
}

\begin{abstract}
Following EU legislation, Romania commit itself to strongly develop the sewage system and the purge of residual waters, both in urban and rural areas, gradually till the 2018-year. Following the statistic data, strong development were registered both concerning the number of cleaning station and the quality of purging. The resulting increasing quantity of sludge could be used in agriculture, forestry, rehabilitation of spoiled areas or energetic culture as long as storage will become more expensive. In 2013 only about $25 \%$ of sludge was used in agriculture half of the target percentage of $50 \%$ for 2020 horizon.
\end{abstract}

Keywords: agriculture, sewage, sludge.

\section{INTRODUCTION}

In Romania in the following years the quantities of waste water will increase following the developing of sewage systems including rural areas. So the quantity materials resulted from purged water will also increase thus creating another problem, the valorisation of organic matters. The EU Council Directive 91/271/ EEC from 21-st of May 1991 regarding urban wastewater treatment, modified and completed by the EU Commission Directive 98/15/EC from 27 of February 1998, is the legal basis of the community in the field of waste water. Following the 91/271/ CEE directive, the Romanian government adopted it entirely through the decision HG 188/2002 modified by HG $352 / 2005$ concerning the management of waste water and their drainage in the environment, in order to avoid pollution and negative effects related to water drainage from certain industrial sectors ( agri-food sectors especially) Romania declared its territory as sensitive area, thus meaning that the urban agglomeration with more than 10.000 equivalent inhabitants, must have a tertiary (most advanced) purge infrastructure especially concerning the recovery of phosphorous and nitrogen nutrients. The secondary purge system (the biological step) is a general rule for the agglomeration less than 10.000 equivalent inhabitants. So following the HG 352/2005 art 5(1) the human agglomerations has to possess sewage systems this way:

a) Till 31 december 2013 the areas with more than 10.000 equivalent inhabitants

b) Till 31 december 2018 the areas between 2000 and 10.000 eqivalent inhabitants

The Article 7(1) claims that the necessary step for cleaning the waters from the sewage system before being evacuated in the environment are:

a) tertiary purge (most advanced) for all human agglomeration with more than 10.000 equivalent inhabitant till 31 of December 2015; b) biological purging ( the second step) for agglomeration between 2000 and 10.000 equivalent inhabitant till 31-st of December 2018

We try to assess the main modalities of sludge valorisation in Romania and to illustrate the condition and the degree the environment 
policies are accomplished using sewage sludge in agriculture. The sludge is reach in organic matters so it could be a good and cheep nutrient in agriculture

\section{MATERIALS AND METHODS}

The data were gathered from those collected by the National Institute of Statistics from Romania and other sources and statistical methods of processing data were used.Following the national strategy, as an intermediary target the purge of waste water were supposed to be:

- $51 \%$ from the total biodegradable content up to 31-st of December 2010

- $61 \%$ up to 31-st of December 2013

- 77\% up to 31-st of December 2015

The collecting of urban sewage water were supposed to be:

- $61 \%$ from the biodegradable content up to 31 December 2010

- $69 \%$ up to 31 December 2013
- $80 \%$ up to 31 December 2015

\section{RESULTS AND DISCUSSION}

Concerning the volume of urban waste in Romania in the years of 2007-2011only about $20-25 \%$ of it was purged (Tab. 1) the rest is unpurged (about 40\%) or not enough purged. The percentage pf purge water is very low facing the $100 \%$ of countries like Austria, Germany or Netherlands [8].

In order to achieve the target of $100 \%$ percentage tertiary purging, Romania invested in cleaning stations, thus in 2013 the cleaning capacity reached $30.1 \%$ (82.23 out of 260) strongly increasing comparatively to 2012 and the capacity should double every year in 2014 and 2015 (Tab. 2).

The evolution of number of the tertiary step station is also reflecting an increasing trend (Tab. $3)$.

Tab. 1. The total volume of urban waste water evacuatedin natural receiversbetween 2007-2011 (millions $\mathrm{m}^{3} /$ year)

\begin{tabular}{cccccccccc}
\hline Anul & Total & \multicolumn{2}{c}{ Purging not necessary } & \multicolumn{2}{c}{ Enough purging } & \multicolumn{2}{c}{ Not enough purging } & \multicolumn{2}{c}{ Unpurged } \\
\hline & & & $\%$ & & $\%$ & & $\%$ & & $\%$ \\
\hline 2007 & 1361.35 & 7.35 & $\mathbf{0 . 5 4}$ & 257.07 & $\mathbf{1 8 . 8 8}$ & 564.25 & $\mathbf{4 1 . 4 5}$ & 532.69 & $\mathbf{3 9 . 1 3}$ \\
\hline 2008 & 1319.30 & 12.70 & $\mathbf{0 . 9 6}$ & 293.78 & $\mathbf{2 2 . 2 7}$ & 487.76 & $\mathbf{3 6 . 9 7}$ & 525.05 & $\mathbf{3 9 . 8 0}$ \\
\hline 2009 & 1296.90 & 8.61 & $\mathbf{0 . 6 6}$ & 301.00 & $\mathbf{2 3 . 2 1}$ & 458.35 & $\mathbf{3 5 . 3 4}$ & 528.95 & $\mathbf{4 0 . 7 9}$ \\
\hline 2010 & 1651.12 & 352.10 & $\mathbf{2 1 . 3 2}$ & 457.33 & $\mathbf{2 7 . 7 0}$ & 304.88 & $\mathbf{1 8 . 4 7}$ & 536.84 & $\mathbf{3 2 . 5 1}$ \\
\hline 2011 & 1325.57 & 0.65 & $\mathbf{0 . 0 5}$ & 342.93 & $\mathbf{2 5 . 8 7}$ & 445.83 & $\mathbf{3 3 . 6 3}$ & 536.18 & $\mathbf{4 0 . 4 5}$ \\
\hline \multicolumn{2}{l}{ Source: Brochure:Situația în România a apelor uzate urbane și a nămolului provenit din stațiile de epurare }
\end{tabular}

Tab. 2. The Romanian tertiary purging capacity and city biochemical consumption in tonnes 02/day

\begin{tabular}{ccccccc}
\hline Purging tertiary & \multicolumn{7}{c}{ Years } \\
\cline { 2 - 7 } station capacity & 2008 & 2009 & 2010 & 2011 & 2012 & 2013 \\
\hline Projected capacity & 13.5 & 22.04 & 42.41 & 40.06 & 45.38 & 293.43 \\
\hline Existed capacity & 7.27 & 12.05 & 11.13 & 16.44 & 22.73 & 82.23 \\
\hline $\begin{array}{c}\text { The volume of } \\
\text { municipality waste }\end{array}$ & 322.14 & 290.9 & 337.9 & 268.6 & 224.5 & 260 \\
\hline Source: insse.ro & & & & &
\end{tabular}

Tab. 3. The numeric evolution of the purge system endowment by tertiary step capabilities

\begin{tabular}{ccccccc}
\hline Years & 2008 & 2009 & 2010 & 2011 & 2012 & 2013 \\
\hline Number & 7 & 16 & 21 & 23 & 23 & 65 \\
\hline Source: insse.ro & & & & &
\end{tabular}


An index of consistency in this politics is the strongly increasing percentage of sludge used in agriculture to $23.68 \%$ from sewage systems and $32.31 \%$ from industrial waste (Tab.4 and Tab. 5)

The sludge use in agriculture is the most complex option: the suitable area for sludge using are calculated considering the following criteria (Order 344/2004):

- The soil PH $>6.5 \%$ thus is already more restrictive than in the other countries

- The maximum quantity applied on soil is $5 t \mathrm{~d} . \mathrm{s}$ (dried substance)/ha

- The maximum allowed nitrogen quantity is 170 $\mathrm{kg} /$ year in vulnerable area to nitrate

- A sustainable program of using the sludge in agriculture could be establish in those condition where:

a) Less than $10 \%$ of the agricultural land suitable for sludge appliance is needed. to use the entire production from within the county

b) The land suitable for using the sludge in agriculture represents more than $10 \%$ but less than $25 \%$ from the total arable land

The Ministry order 344/2004 also contains the necessary normative and conditions in order for a suitable sludge to be applied in agriculture:

- The maximum concentration of heavy metals in soil to be over applied in $\mathrm{mg} / \mathrm{kg}$ of dried substance
- The maximum concentration of heavy metals in sludge to be applied on soil in $\mathrm{mg} / \mathrm{kg}$ of dried substance

- The limit value of heavy metals for the agriculture land for a 10 years average administration (in $\mathrm{kg} / \mathrm{ha} /$ year)

The use of sludge waste is strictly forbidden to fruit and vegetables growing in bushes, vineyards, pastures and for orchards only 10 month in advance to cropping. In forestry the use is allowed only for nurseries.

Using the energetic willow, which is a plant that can be cultivated in contaminated soils, is a widespread solution especially in Scandinavia's countries, because of its ability to take up harmful substances and accumulate it in aboveground biomass.Willow plants may be used to extract heavy metals from contaminated soils due to their tolerance to specific heavy metals, adaptation to soil and climate characteristics, heavy metal uptake capability and spatial fitting of roots to pollution distribution (Jama and Novak. 2012). This could be the final step before the purified waste be drained in the environment. In Romania. close to the city of Miercurea Ciuc a willow plantation obtained good results in filtering city waste

The benefits of sewage use should extend in the area of abandoned and spoiled terrains. where the massive administration of sewage are

Tab. 4. The quantity of sludge coming from urban sewage systems

\begin{tabular}{ccccccccc}
\hline & 2006 & \multicolumn{7}{c}{ Years } \\
\cline { 3 - 8 } & & 2007 & 2008 & 2009 & 2010 & 2011 & 2012 \\
\hline Total sludge & \multirow{2}{*}{$\begin{array}{c}\text { Thousands cubic } \\
\text { meters } \\
\text { /year }\end{array}$} & 157920 & 95456 & 224958 & 22072 & 16812 & 33871 & 42953.55 \\
\cline { 3 - 8 } $\begin{array}{c}\text { Sludge used in } \\
\text { agriculture }\end{array}$ & 64.79 & 80.02 & 713.32 & 2977.5 & 2204.7 & 3505.6 & 10171.01 \\
\hline & Percentage & $0.04 \%$ & $0.08 \%$ & $0.32 \%$ & $13.49 \%$ & $13.11 \%$ & $10.3 \%$ & $23.68 \%$ \\
\hline Source: insse.ro & & & & & & & &
\end{tabular}

Tab. 5. The quantity of sludge coming from industrial waste water

\begin{tabular}{|c|c|c|c|c|c|c|c|c|}
\hline \multirow{2}{*}{\multicolumn{2}{|c|}{2006}} & \multicolumn{7}{|c|}{ Years } \\
\hline & & 2007 & 2008 & 2009 & 2010 & 2011 & 2012 & \\
\hline Total sludge & \multirow{2}{*}{$\begin{array}{l}\text { Thousands } \\
\text { cubic meters } \\
\text { /year }\end{array}$} & 46004 & 63589 & 55961 & 27143 & 5323 & 10222 & 13622 \\
\hline \multirow[t]{2}{*}{$\begin{array}{l}\text { Sludge used in } \\
\text { agriculture }\end{array}$} & & 4130.1 & 216.3 & 1658.8 & 1647.8 & 87.57 & 49.59 & 4400.99 \\
\hline & Percentage & $8.98 \%$ & $0.34 \%$ & $2.96 \%$ & $6.07 \%$ & $1.65 \%$ & $0.49 \%$ & $32.31 \%$ \\
\hline
\end{tabular}


needed in order to obtain a sustainable vegetation on such area characterised by lack of surface soil layer. This kind of area are usually: ex industrial areas, mining waste deposits. quarries and closed waste storage capacities. In Romania following the industrial past and due to transition to the new economy a lot of such areas are spread along the territory mostly of them not being rehabilitated thus generating pollution. As mentioned in the National strategy of sewage waste management in Romania are 675 deposits of mining waste, in 21 counties,having a total surface of $9260 \mathrm{Ha}$. Mostly of them are coal power plant deposits waste and coal exploitations (93\%). 5\% different mining exploitation and $2 \%$ were radioactive mining.

\section{CONCLUSION}

In the years of 2011-2012 only about 25\% of mudcollected waste was processed in such a way that it could be used in agriculture. No data are available after these period. For the horizon of 2020 programs. this percentage should be riseto at least $50 \%$ from the entire sludge quantityas stipulated in HG 349/2005 Art 6. Not only the percentage should double but the collected sewage quantity will increase.

In order to develop the cleaning of residual waters both domestic and industrial. many investments should be made in building new cleaning station and develop the existing stations. A big percentage of sludge is still deposited in improperly way
For these. a financial plan should be developed in order to obtain a good costs/benefits ratio.

- A quality management plan should be developed and implemented during the activities in order to accomplish the results

- The needed investment funds should be available for the future

\section{REFERENCES}

1. Jama A, Nowak W (2012).Willow (Salix viminalis L.) in purifying sewage sludge treated soils. Polish Journal of Agronomy 9: 3-6.

2. Neamt I, Ionel I,Vlaicu I (2013). Valorificarea energetică a nămolului în stațiile municipale de epurare din România Buletinul AGIR, Supliment 1/2013 Pag. 34-37.

3. Romanian Ministry of Environment, Water Management, and Forests.Brochure: Situația în România apelor uzate urbane şi a nămolului provenit din stațiile de epurare, Broşură pentru public

4. Bucharest 2012 (http://www.rowater.ro/TEST/Brosuraape-uzate-pentru-public-2012.pdf)

5. Romanian Ministry of Environment Water Management and Forests, Brochure: National strategy of sewage waste management (2012)

6. (http://mmediu.ro/new/wp-content/uploads/2014/01/NationalWasteStrategy.pdf)

7. Romanian Ministry of Agriculture of Romania . Order $344 / 2004$

8. (http://www.legex.ro/Ordin-344-2004-43800.aspx)

9. Romanian National institute of Statistics: www.insse.ro.

10. www.kwg.ro.

11. http://www.waterworld.com/articles/2013/08/ wastewater-collection-and-treatment-improvements-ineurope-says-eu-report.html 